\title{
THE USE OF A SERIOUS GAME AND ACADEMIC PERFORMANCE OF UNDERGRADUATE ACCOUNTING STUDENTS: AN EMPIRICAL ANALYSIS
}

\author{
Dr. Rodrigo Fernandes MALAQUIAS \\ School of Business and Management \\ Federal University of Uberlandia \\ Uberlandia, BRAZIL \\ Dr. Fernanda Francielle de Oliveira MALAQUIAS \\ School of Business and Management \\ Federal University of Uberlandia \\ Uberlandia, BRAZIL \\ Dermeval M. BORGES JUNIOR \\ Graduate Program in Accounting \\ Federal University of Uberlandia \\ Uberlandia, BRAZIL \\ Pablo ZAMBRA \\ Graduate Program in Accounting \\ Federal University of Uberlandia \\ Uberlandia, BRAZIL
}

\begin{abstract}
The literature on serious games (SGs) indicates that they are very useful tools to improve the teaching/learning process. In this paper, we analyze some potential benefits of a SG on academic performance of undergraduate accounting students. The database is comprised of scores obtained by students during an undergraduate discipline related with accounting history. The game was presented to the students during the academic semester of the discipline; they also developed an academic activity using the concepts of this game. The main results of the paper indicate that students who used the game and scored the maximum grade in this activity also registered higher indexes of academic performance in such discipline. These results reinforce the benefits of the SG to interact with undergraduate students and teach academic content.
\end{abstract}

Keywords: Accounting, education, serious games.

\section{INTRODUCTION}

In the last decades, the increasingly use of multimedia technologies, educational computer games, teleconferencing, e-learning, and other advancements involving information technologies has significantly changed the ways of teaching academic and professional skills to both adults and children (Girard, Ecalle \& Magnant, 2013; Dobrescu, Greiner \& Motta, 2015). These advancements also generate challenges for companies and for teaching in the field of business, and this scenario also comprises the academic education of professionals in the area of accounting (Chang \& Hwang, 2003; Mohamed \& Lashine, 2003; Lillie \& Wygal, 
2011; Abou-Warda, 2016; Apostolou, Dorminey, Hassell \& Rebele, 2016). Furthermore, these changes affects "the educational system in general and instructional methods in particular" (Bayrak, 2008, p. 53).

One of these changes refers to the fact that students use technology with higher intensity, and it provides opportunities for teachers to update the content of disciplines (Chang \& Hwang, 2003; Apostolou et al., 2016). Therefore, teachers can expand the use of technological resources in the classroom. Different studies (Boulianne, 2014; Chang \& Hwang, 2003) have demonstrated the use of technology in the field of accounting, as well as the positive effects of integrated technologies to accounting teaching (Lillie \& Wygal, 2011; Rackliffe \& Regland, 2016; Willis, 2016). Wireless devices such as Ipods have brought efficiency and efficacy to accounting students due to their portability (Richardson, Dellaportas, Perera \& Richardson, 2013) and social networks, as Facebook, also have been used (Stone, Fiedler \& Kandunias, 2014).

More recently, new computer tools called serious games (SGs) appeared in the educational games market. In general, SGs are technologies in the form of software products, computer games or video games that are not conventionally used only for entertainment, but for useful purposes, such as education, training, knowledge acquisition, skills development, among many others (Girard et al., 2013). Bellotti, Kapralos, Lee, Moreno-Ger and Berta (2013) emphasize that SGs have two main purposes, first they should be entertaining, that is, they must be considered attractive for a large public in a similar way to conventional games, and they must be educational, that is, reach specific educational objective.

From a pedagogical perspective, SGs increase the attractiveness and effectiveness of learning since they offer to the students active, experiential, situated and problem-based learning experience (Anolli, Mantovani, Confalonieri, Ascolese \& Peveri, 2010; Connolly, Boyle, MacArthur, Hainey \& Boyle, 2012). In Brazil, a serious game was developed to teach accounting history: DEBORAH Game. This game was developed at GETEC-FEA-USP (this is the Lab of Technology Education in Accounting, University of Sao Paulo, Brazil), headed by Professor Edgard Cornacchione (DEBORAH Game, 2017). Considering that serious games can improve the teaching process, the aim of this paper is to analyze whether students more engaged in the use of DEBORAH Game during the activities of the accounting history discipline presented higher levels of academic performance in such discipline. We expect a positive effect of the use of serious game on academic performance. The theoretical review that supports the hypothesis of this study is presented in the following section.

There are different focus and paradigms of accounting history, as well as different are the periods of time and research themes in accounting history (Gomes, 2008). "The key interdisciplinary focus in historical accounting research derives from the application of an array of theoretical perspectives drawn from other disciplines, such as sociology, political and organizational theory, law and education" (Carnegie, 2014, p. 1242). The study and deepening of accounting history allow a comprehensive vision of accounting, highlighting it not as a technical concept of business world, but as a social conception (Gomes, 2008; Carnegie, 2014).

\section{THEORETICAL REVIEW}

Being considered as a global revolution (Anolli et al., 2010), the use of serious games in education has been investigated by many researchers. Serious games were already found to be useful to help students with intellectual disabilities (Malaquias, Malaquias, Lamounier Jr. \& Cardoso, 2013), to improve cognitive functions (Abreu, Carvalho, Werneck \& Costa, 2011), to contribute with the development of language skills (Alyaz \& Genc, 2016), and to trigger 
emotional involvement in users (Anolli et al., 2010). In a general way, there is a consensus about the positive outcomes and benefits of games (Connolly et al., 2012; Bellotti et al., 2013). In digital settings, collaborative learning is also gaining attention from researchers (Samur, 2011).

Jackson and McNamara (2013) argue that the main strength of educational games is their potential to increase student's motivation and commitment to educational activities. According to Hamari, Sharnoff, Rowe, Coller, Asbell-Clarke and Edwards (2016), educational games can be useful because, through them, students learn how to solve complex problems in a natural way, since the problems in the games are usually easy at the beginning and become difficult progressively as the skills of the players develop. In addition, the authors emphasize that students are motivated to learn using games, since learning in games occurs through conjectures, trials and reflections that happen spontaneously in the virtual simulation of the events.

Backlund and Hendrix (2013) synthesized the current state of studies regarding the effectiveness of learning based on SGs and the development and use of these games in practice, covering different areas of knowledge. Of the $\mathbf{4 0}$ studies reviewed by Backlund and Hendrix (2013), 29 indicated evidences that SGs indeed have a positive effect on learning, seven studies have been neutral regarding the implications of SGs in learning and only two indicated negative results.

In a similar study, Connoly et al. (2012) examined 129 papers in the literature on computer games and SGs regarding the possible impacts of these games on learning, skills development and player's commitment. These authors found evidences that the use of digital games for learning purposes has been employed in the most diverse curricular areas, especially in health, business and social issues, and that the main results of those studies involved knowledge acquisition, content understanding and motivational and effective issues (Connoly et al., 2012). Figure 1 indicates the main characteristics of SGs; these characteristics are expected to present a positive effect on the teaching/learning process.

\begin{tabular}{|c|c|c|}
\hline Characteristic & Contribution & Authors \\
\hline Entertaining & $\begin{array}{l}\text { SGs are entertaining such as conventional games, } \\
\text { thus increasing students' engagement and making } \\
\text { learning enjoyable. }\end{array}$ & $\begin{array}{l}\text { Bellotti et al. (2013) } \\
\text { Jackson and } \\
\text { McNamara (2013) } \\
\text { Hamari et al. (2016) }\end{array}$ \\
\hline Purpose & $\begin{array}{l}\text { Differently of conventional games, SGs are not } \\
\text { used only for entertainment, but for useful } \\
\text { purposes, such as education, training, skills } \\
\text { development, among many others. }\end{array}$ & $\begin{array}{l}\text { Marsh (2011) } \\
\text { Girard et al. (2013) } \\
\text { Bellotti et al. (2013) }\end{array}$ \\
\hline Experiential & $\begin{array}{l}\text { SGs provide opportunities for experience and } \\
\text { emotion through the virtual simulation } \\
\text { environment, thus making the learning process to } \\
\text { happen spontaneously. }\end{array}$ & $\begin{array}{l}\text { Raybourn (2007) } \\
\text { Marsh (2011) } \\
\text { Hamari et al. (2016) }\end{array}$ \\
\hline Flexibility & $\begin{array}{l}\text { SGs provide a large range of learning scenarios } \\
\text { and may be used in various knowledge areas. }\end{array}$ & $\begin{array}{l}\text { Westera, Nadolski, } \\
\text { Hummel and } \\
\text { Wopereis (2008) } \\
\text { Breuer and Bente } \\
\text { (2010) } \\
\text { Backlund and Hendrix } \\
\text { (2013) }\end{array}$ \\
\hline
\end{tabular}

Figure 1. Main characteristics of SGs according to the literature

Hess and Gunter (2013) compared the experiences and performance between American History online courses based on SG and non-SG based with a sample of 92 students from each 
course randomly chosen. Among the results obtained in the mentioned study, they observed that, on average, the students of SG-based course in comparison to the students of the non SG-based course took more time to complete the course, 145.8 days versus 112.6 days, and had better academic performance, with average grade of $97.8 \%$ versus $88.2 \%$. In addition, from qualitative questions, it was found evidences of higher levels of intrinsic motivation in students of the SG-based course.

Cook, McAloon, O'Neill and Beggs (2012) studied the impact of a web-based simulation gaming platform on the performance of students in the last year of the nursing course about life support trainings. Among the results of the research, it was verified that the simulation gaming platform had an important role in the development of knowledge, psychomotor skills and decision making process of nursing students, especially with regard to activities such as equipment checking, airways evaluation and safe and effective use of defibrillator.

Previous studies have also demonstrated evidences about the positive impact that SGs have on language learning. Guillén-Nieto and Aleson-Carbonell (2012) verified statistically significant differences between the performance of students before and after being submitted to SG, so that there were advances in terms of English language knowledge in aspects such as intercultural awareness, intercultural communicative competence and intercultural knowledge. Similarly, Connolly, Stansfield and Hainey (2011), from questionnaires applied to students, showed that the majority of surveyed students stated that the SG delivered motivational experience to learn foreign language during a long time period.

Heili and Michel (2011) analyzed the potential of SGs for professional and pedagogical purposes through an experiment with a sample of 66 students trained in sales, which were divided in two groups, one of SGs players and other of non-SG players. In overall, the results indicated that SGs had a positive effect on students that already had a previous sale experience and had limited potential for other novice sale students. Despite the benefits from the use of SGs, it is also relevant to consider that the teachers need to be trained before the effective use of the game in the teaching process (Alyaz \& Genc, 2016).

Considering the characteristics available in Figure 1 , as well as the empirical evidences presented in previous paragraphs, we argue that SGs represent effective tools for the development of learning and other aspects that are related to the educational process in different areas of knowledge. Based on this reasoning, we also expect that the use of the serious game presents a positive effect for accounting students to study accounting history. Therefore, we develop the following hypothesis:

H1: the use of serious game has a positive effect on academic performance of undergraduate students.

METHOD

The data used in this study involves: i) scores obtained by undergraduate students in an activity with questions regarding the content available in the serious game; ii) scores obtained by students when they developed a power-point presentation, involving the content of accounting history; and iii) scores obtained by students in the final exam of the discipline of accounting history. The content of the discipline is related to accounting history. During this discipline, the professor presented the serious game in the classes and encouraged the students to access and use DEBORAH Game (2017). After it, the professor developed an activity with eight questions (multiple choice) regarding the serious game. To answer these questions, students should access the Game and navigate through its functionalities. A number of $\mathbf{3 9}$ undergraduate students started the discipline and coursed it up to its end; all of 
them were encouraged to access the serious game and explore its functionalities. Of this number, 37 students answered the serious game activity.

After using the Game, the undergraduate students also had two academic activities: i) a power-point presentation, regarding accounting history; and ii) a final exam, involving the content of the discipline. All the grades obtained by students were converted in percentage (for example, the maximum grade in the power-point presentation was 14.0 points; a student with $\mathbf{1 2 . 6}$ points had $\mathbf{9 0 \%}$ in this activity). In order to test the hypothesis of the study, we compare the academic performance of these two activities (power-point presentation and the final exam) between two groups of students: students with higher scores in the activity using the serious game, and students with lower scores in such activity.

\section{RESULTS AND DISCUSSION}

The average grade obtained by the 37 undergraduate students who used the serious game was $91.1 \%$. The minimum grade was $52.1 \%$ and the maximum was $100 \%$. These results indicate that the majority of the students used the game and understood the questions properly. Based on these grades, we divided the sample in two groups: Group A: students who registered $100 \%$ of grade in the activity involving the serious game (20 students); Group B: students who registered less than $100 \%$ in the activity involving the serious game, or students that did not make this activity (19 students).

Table 1 reports the average grade of the final test, obtained by the students. It is important to note that the students developed both activities (final test and power-point presentation) after the first contact with the serious game. As the results indicate, the group of students with better performance in the serious game activity (Group A) also presented the better performance in the final test of the discipline $(86.429 \%)$. On average, these students (Group A) presented a difference of 12.594 percentage points in comparison to their counterparties (73.835\%). This difference is statistically significant at $5 \%$ (sig.: 0.0115 ).

Table 1. Average grades on the final test, considering the performance on the activity with the serious game

\begin{tabular}{llllll}
\hline Group & n & Mean & Std. Err. & \multicolumn{2}{c}{ [95\% Conf. Interval] } \\
\hline A & 20 & $\mathbf{8 6 . 4 2 9}$ & 2.594 & 80.999 & 91.858 \\
B & 19 & 73.835 & 4.018 & 65.392 & 82.277 \\
Combined & 39 & $\mathbf{8 0 . 2 9 3}$ & 2.548 & 75.134 & 85.452 \\
Difference & & 12.594 & 4.734 & 22.186 & 3.002 \\
\hline
\end{tabular}

Notes: t-statistic (for mean difference = 0): 2.6603 (sig.: 0.0115; p < 5\%)

Considering the results of Table 1, the use of the serious game can contribute with the academic performance of undergraduate students. The Game also can motivate students in obtaining higher scores in the activities related to this field (accounting history). On the other hand, the results reported in Table 2 indicate that the performance in the activity involving power-point presentation were not affected by the use of this game.

Table 2. Average grades on the power-point presentation, considering the performance on the activity with the serious game

\begin{tabular}{llllll}
\hline Group & $\mathbf{n}$ & Mean & Std. Err. & \multicolumn{2}{c}{ [95\% Conf. Interval] } \\
\hline A & 20 & 91.250 & 1.172 & 88.796 & 93.704 \\
B & 19 & 86.090 & 4.908 & 75.780 & 96.401 \\
Combined & 39 & 88.736 & 2.467 & 83.742 & 93.730 \\
Difference & \multicolumn{2}{c}{5.160} & 4.929 & 15.147 & -4.828 \\
\hline
\end{tabular}


Our theoretical review indicates that SGs can contribute to academic performance, and we have proposed the hypothesis of the study: H1: the use of serious game has a positive effect on academic performance of undergraduate students. Observing the results available in Table 1, about the final test grades of the discipline after students have been submitted to the SG, they corroborate with several previous studies in the literature that had already demonstrated the benefits of SGs on students' academic performance. These studies comprise the research of Hess and Gunter (2013) with students of American History course, Cook et al. (2012) with nursing students, Heili and Michel (2011) with sales students and Guillén-Nieto and AlesonCarbonell (2012) and Connolly, Stansfield and Hainey (2011) with foreign language students. However, it is important to mention that, unlike what was expected, the results of the powerpoint presentation scores, as indicated in Table 2, did not show improvements on students' performance from the use of SG, which does not corroborate with most studies about the topic. This result (from Table 2) also does not support H1. One of the possible explanations for this divergent outcome may be the fact that the SG used as a support tool to teach accounting history does not necessarily develop communication and public speaking skills, which are fundamental for a good presentation performance. Another explanation may be related to the findings of Heili and Michel (2011) that students with previous experiences on the subject take better advantage of the SGs and, consequently, perform better. Therefore, perhaps separating the groups based on students' previous experiences rather than using grades as the main criteria may provide conclusive results for this topic. It is also important to consider that the power-point presentation was a group activity. The potential positive effects of the SG to this activity maybe disperse among the different students that compose the groups.

According to the empirical analysis of this paper, the research hypothesis was partially supported. Since the sample of this study is comprised of undergraduate students of only one class (number of students in the final sample is 39), caution is needed for generalizations. Therefore, further research is also recommended to analyze other potential effects of SGs in the academic content of accounting course, especially in subjects that contain higher levels of theoretical content (rather than practical content).

\section{CONCLUSION}

Considering that technology can contribute to the teaching / learning process of undergraduate students, we develop this paper in order to analyze the potential effects of the use of a serious game in a discipline of accounting history. To do so, the SG called DEBORAH Game (2017) was presented to students during the classes of accounting history and the students have used the game to attend an activity of the discipline. When using the game, students were able to navigate, access, study and train content about ancient accounting history, medieval accounting history, modern accounting history, and contemporary accounting history (DEBORAH Game, 2017). During the accounting history course, students also developed other activities, as well as study the academic content taught by the teacher of the discipline. After using the game, we observed the students' performance in two academic activities: a power-point presentation (in groups), and a final exam of the discipline. Students also developed an activity with a set of questions about content available in the SG, and we divided the class (in the analysis of this study) in two groups: a group of students with scored the total in this activity, and a group of students that does not scored the total in this activity (or did not make the activity).

In general, the results of this paper were in line with previous research that also indicated improved students' academic performance through SGs, such as Connolly, Stansfield and Hainey (2011), Heili and Michel (2011), Guillén-Nieto and Aleson-Carbonell (2012), Cook et 
al. (2012) and Hess and Gunter (2013). Despite of this, when analyzing the students' performance in a power-point presentation, the difference of performance between the two groups was positive, but not statistically significant. Therefore, the hypothesis of the research (H1: the use of serious game has a positive effect on academic performance of undergraduate students) was partially supported.

This study can expand previous research about the benefits of SGs in undergraduate courses, especially because we analyze a specific content in the accounting course: accounting history. Some limitations are present in this study, and the first is the absence of control variables to develop the quantitative procedures. Variables such as gender, age, professional experience, perception of academic performance in the entire course, among others, can contribute to refine the analysis of the benefits that students can obtain from SGs.

Another limitation of this research is the sample size. The empirical analysis was developed considering only one class of students, with 39 participants, which has an impact on the generalization of the results. Moreover, the absence of significance in the second analysis (with the results in the activity of power-point presentation) may be affected by the sample size, and new research considering different classes of students can improve the understanding of the effects of SGs in academic performance of undergraduate students.

It is also important to comment a potential case of endogeneity with the database; that is, students motivated to reach higher levels of performance in the accounting course could also be motivated to achieve better performance in the tests/exams of the accounting history discipline as well as in the activity that depends of the SG use. Therefore, in this case, the main explanation for the positive difference is the motivation of the students, and not necessarily the effects of using a SG to study. Nevertheless, the theoretical review and previous research indicate that SGs contain a set of characteristics (such as entertaining, purpose, experiential and flexibility) which contributes to students use it and fix academic content about accounting history. So, even with some concern regarding endogeneity in the case of this study, the benefits of the SG to teach accounting history are more comprehensive than the aspects evaluated in this paper.

Regarding further research, we recommend new studies about the use of serious games to teach practical content of basic accounting, especially considering the role of mobile devices to the interaction of the students and the content of the game. We also indicate for future research the analysis of the perception of teachers and students about the acceptance of serious games in the undergraduate accounting courses.

ACKNOWLedgemenTS: We would like to thank Prof. Edgard Cornacchione, PhD, for the authorization to use the DEBORAH Game to develop an academic study about its use by undergraduate students. We gratefully acknowledge the helpful comments of the anonymous reviewer during the revision of the manuscript. The author Pablo Zambra would like to thank FAPEMIG for the scholarship. 


\section{BIODATA and CONTACT ADDRESSES of AUTHORS}

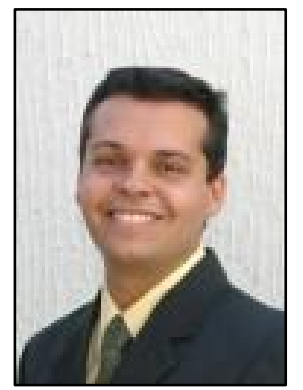

Rodrigo Fernandes MALAQUIAS is a Full Time Professor at Universidade Federal de Uberlandia UFU, Brazil. In 2012, he received his PhD in Business Administration from Escola de Administraçao de Empresas de Sao Paulo da Fundaçao Getulio Vargas FGV-EAESP, Brazil. In 2015, he was a Visiting Research Scholar at DePaul University in Chicago, USA. His research includes finance, accounting, mobile banking, e-commerce, and crosscountry studies.

Rodrigo Fernandes MALAQUIAS

Av. Joao Naves de Avila, 2121, Bloco: 1F, 1F-200, Campus Santa Monica, Uberlandia/MG, Brazil. 38400-902

Phone: +55 (34) 3239-4132

E-mail: rodrigofmalaquias@yahoo.com.br

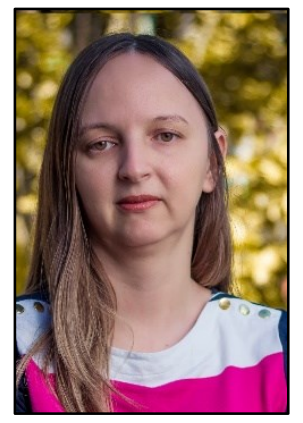

Fernanda Francielle de Oliveira MALAQUIAS is a Full time Professor at Universidade Federal de Uberlandia, Brazil. She received her PhD in Electrical Engineering from Universidade Federal de Uberlandia. She also holds a MS degree in Computer Science. In 2015, she was a Visiting Research Scholar at DePaul University in Chicago, USA. Her research focuses on mobile banking, information systems, and virtual reality applications.

Fernanda Francielle de Oliveira MALAQUIAS

Av. Joao Naves de Avila, 2121, Bloco: 1F, 1F-216, Campus Santa Monica, Uberlandia/MG, Brazil. 38400-902

Phone: +55 (34) 3239-4132

E-mail: fernandafrancielle@gmail.com

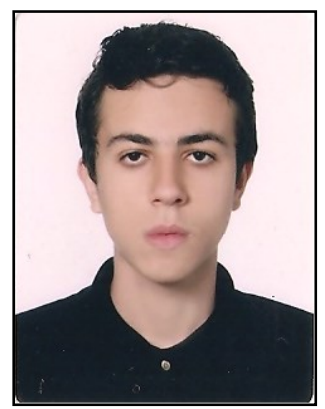

Dermeval M. BORGES JUNIOR is currently a doctoral student in Accounting Sciences at Federal University of Uberlandia (UFU), Brazil. He also has a bachelor's degree in business administration (2015) and a master's degree in business administration (2017), both from the Federal University of Uberlandia (UFU), Brazil. His academic interest areas are business administration, finance and operational research.

Dermeval M. BORGES JUNIOR

Av. Joao Naves de Avila, 2121, Bloco: 1F, 1F-248, Campus Santa Monica, Uberlandia/MG, Brazil. 38400-902

Phone: +55 (34) 3291-5904

E-mail: dermevaljr14@ufu.br 


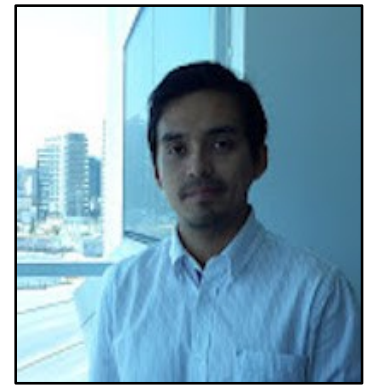

Pablo ZAMBRA is an Auditor, at Deloitte (Chile). His experience as auditor in Deloitte is mainly oriented to the mining sector of Chile. He has a specialization in International Financial Reporting Standard and experience as a part time professor of auditing and mining topics at the Universidad Católica del Norte (UCN), Chile. His academic interest areas are Financial intruments, IFRS, auditing. He holds a Master's degree from Universidade Federal de Uberlanda, Brazil. Pablo Zambra thanks FAPEMIG for the scholarship.

Pablo ZAMBRA

Av. Joao Naves de Avila, 2121, Bloco: 1F, 1F-248, Campus Santa Monica, Uberlandia/MG, Brazil. 38400-902

Phone: +55 (34) 3291-5904

E-mail: zambra.dgh@gmail.com

\section{REFERENCES}

Abou-Warda, S. H. (2016). New educational services development: framework for technology entrepreneurship education at universities in Egypt. International Journal of Educational Management, 30(5), 698-717. doi: 10.1108/IJEM-11-20140142

Abreu, P. F., Carvalho, L. F. V., Werneck, V. M. B., \& Costa, R. M. E. M. (2011). Integrating Multi-agents in a 3D Serious Game Aimed at Cognitive Stimulation. Virtual and Mixed Reality - Systems and Applications. VMR 2011 Lecture Notes in Computer Science, vol. 6774. Springer, 217-226. doi: 10.1007/978-3-642-22024-1_24

Alyaz, Y., \& Genc, Z. S. (2016). Digital Game-Based Language Learning in Foreign Language Teacher Education. Turkish Online Journal of Distance Education, 17(4), 130-146. doi: $10.17718 /$ tojde.44375

Anolli, L., Mantovani, F., Confalonieri, L., Ascolese, A., \& Peveri, L. (2010). Emotions in Serious Games: From Experience to Assessment. International Journal of Emerging Technologies in Learning, 5(Special Issue 3: "Creative Learning with Serious Games"), 7-16. doi: 10.3991/ijet.v5s3.1496

Apostolou, B., Dorminey, J. W., Hassell, J. M., \& Rebele, J. E. (2016). Accounting education literature review (2015). Journal of Accounting Education, 35, 20-55. doi: 10.1016/j.jaccedu.2016.03.002

Backlund, P., \& Hendrix, M. (2013). Educational Games - Are They Worth the Effort? A literature survey of the effectiveness of serious games. In Games and virtual worlds for serious applications (VS-GAMES), 2013 5th international conference on (pp. 18). IEEE. doi: 10.1109/VS-GAMES.2013.6624226

Bayrak, C. (2008). Effects of Computer Simulations Programs on University Students' Achievements in Physics. Turkish Online Journal of Distance Education, 9(4), 53-62. Retrieved from: http://tojde.anadolu.edu.tr/makale_goster.php?id=441. Accessed in September 9, 2017.

Bellotti, F., Kapralos, B., Lee, K., Moreno-Ger, P., \& Berta, R. (2013). Assessment in and of Serious Games: An Overview. Advances in Human-Computer Interaction, 2013, 111. doi: 10.1155/2013/136864 
Boulianne, E. (2014). Impact of accounting software utilization on students' knowledge acquisition An important change in accounting education. Journal of Accounting \& Organizational Change, 10(1), 22-48. doi: 10.1108/JAOC-12-2011-0064

Breuer, J. S., \& Bente, G. (2010). Why so serious? On the relation of serious games and learning. Eludamos Journal for Computer Game Culture, 4(1), 7-24. Retrieved from: http://www.eludamos.org/index.php/eludamos/article/viewArticle/vol4no1-2. Accessed in September 9, 2017.

Carnegie, G. D. (2014). The present and future of accounting history. Accounting, Auditing \& Accountability Journal, 27(8), 1241-1249. doi: 10.1108/AAAJ-05-2014-1715

Chang, C. J., \& Hwang, N.C. R. (2003). Accounting education, firm training and information technology: a research note. Accounting Education, 12(4), 441-450. doi: $10.1080 / 0963928032000065557$

Connolly, T. M., Boyle, E. A., MacArthur, E., Hainey, T. \& Boyle, J. M. (2012). A systematic literature review of empirical evidence on computer games and serious games. Computers \& Education, 59(2), 661-686. doi: 10.1016/j.compedu.2012.03.004

Connolly, T. M., Stansfield, M., \& Hainey, T. (2011). An alternate reality game for language learning: ARGuing for multilingual motivation. Computers \& Education, 57(1), 13891415. doi: 10.1016/j.compedu.2011.01.009

Cook, N. F., McAloon, T., O'Neill, P., \& Beggs, R. (2012). Impact of a web based interactive simulation game (PULSE) on nursing students' experience and performance in life support training - A pilot study. Nurse Education Today, 32(1), 714-720. doi: 10.1016/j.nedt.2011.09.013

DEBORAH Game (2017). DEBORAH - Double Entry Bookkeeping OR Accounting History. About. Retrieved from http://deborahahg.wixsite.com/deborah/about. Accessed in May 5th, 2017.

Dobrescu, L. I., Greiner. B., \& Motta, A. (2015). Learning economics concepts through gameplay: An experiment. International Journal of Educational Research, 69, 23-37. doi: 10.1016/j.ijer.2014.08.005

Girard, C., Ecalle, J., \& Magnant, A. (2013). Serious games as new educational tools: how effective are they? A meta-analysis of recent studies. Journal of Computer Assisted Learning, 29(3), 207-219. doi: 10.1111/j.1365-2729.2012.00489.x

Gomes, D. (2008). The interplay of conceptions of accounting and schools of thought in accounting history. Accounting History, 13(4), 479-509. doi: $10.1177 / 1032373208095480$

Guillén-Nieto, V., \& Aleson-Carbonell, M. (2012). Serious games and learning effectiveness: The case of It's a Deal!. Computers \& Education, 58(1), 435-448. doi: 10.1016/j.compedu.2011.07.015

Hamari, J., Sharnoff, D. J., Rowe, E., Coller, B., Asbell-Clarke, J., \& Edwards, T. (2016). Challenging games help students learn: An empirical study on engagement, flow and immersion in game-based learning. Computers in Human Behavior, 54(1), 170179. doi: 10.1016/j.chb.2015.07.045

Heili, J., \& Michel, H. (2011, October). Do students trained using serious games become better sales representatives? an experiment to study the performance of academic serious games. In European Conference on Games Based Learning (p. 230). Academic Conferences International Limited. Retrieved from: http://ja.games.free.fr/ludoscience/EVirtuoses/AppelAComEVirtuo2012/Articles/0 1_ImpactSG.pdf. Accessed in September 9, 2017. 
Hess, T., \& Gunter, G. (2013). Serious game-based and nongame-based online courses: Learning experiences and outcomes. British Journal of Educational Technology, 44(3), 372-385. doi: 10.1111/bjet.12024

Jackson, G. T., \& McNamara, D. S. (2013). Motivation and Performance in a Game-Based Intelligent Tutoring System. Journal of Educational Psychology, 105(4), 1036-1049. doi: $10.1037 / a 0032580$

Lillie, R. E., \& Wygal, D. E. (2011). Virtual Office Hours (VOH) in accounting coursework: Leveraging technology to enhance an integrative learning environment. Journal of Accounting Education, 29(1), 1-13. doi: 10.1016/j.jaccedu.2011.10.002

Malaquias, F. F. O, Malaquias, R. F., Lamounier Jr., E. A., \& Cardoso, A. (2013). VirtualMat: A serious game to teach logical-mathematical concepts for students with intellectual disability. Technology and Disability, 25, 107-116. doi: 10.3233/TAD-130375

Marsh, T. (2011). Serious games continuum: Between games for purpose and experiential environments for purpose. Entertainment Computing, 2(2), 61-68. doi: 10.1016/j.entcom.2010.12.004

Mohamed, E. K., \& Lashine, S. H. (2003). Accounting knowledge and skills and the challenges of a global business environment. Managerial Finance, 29(7), 3-16. doi: 10.1108/03074350310768319

Rackliffe, U. R., \& Ragland, L. (2016). Excel in the accounting curriculum: perceptions from accounting professors. Accounting Education, 25(2), 139-166. doi: 10.1080/09639284.2015.1126791

Raybourn, E. M. (2007). Applying simulation experience design methods to creating serious game-based adaptive training systems. Interacting with Computers, 19(2), 206214. doi: 10.1016/j.intcom.2006.08.001

Richardson, P., Dellaportas, S., Perera, L., \& Richardson, B. (2013). Students' perceptions on using iPods in accounting education: a mobile-learning experience. Asian Review of Accounting, 21(1), 4-26. doi: 10.1108/13217341311316922

Samur, Y. (2011). Using Wikis as a Support and Assessment Tool in Collaborative Digital Game-Based Learning Environments. Turkish Online Journal of Distance Education, 12(2), 70-75. Retrieved from:

http://tojde.anadolu.edu.tr/makale_goster.php?id=664. Accessed in September 9, 2017.

Stone, G., Fiedler, B. A., \& Kandunias, C. (2014). Harnessing Facebook for Student Engagement in Accounting Education: Guiding Principles for Accounting Students and Educators. Accounting Education: An International Journal, 23(4), 295-321. doi: 10.1080/09639284.2014.908730

Westera, W., Nadolski, R. J., Hummel, H. G. K. \& Wopereis, I. G. J. H. (2008). Serious games for higher education: a framework for reducing design complexity. Journal of Computer Assisted Learning, 24(5), 420-432. doi: 10.1111/j.13652729.2008.00279.x

Willis, V. F. (2016). A model for teaching technology: Using Excel in an accounting information systems course. Journal of Accounting Education, 36, 87-99. doi: 10.1016/j.jaccedu.2016.05.002 